\title{
Timeline of Safavid Capital Cities and Major Structures
}

TABRIZ (I 5 OI-I $555 / 6$ )

Shah Isma'il (I 50I-I 524)

Ancestral shrine in Ardabil; Dar al-Hadith (Reading Hall for the Hadith)

Governors of Isfahan, Mausoleum of Harun-e Velayat (I 5 I3) and Masjed-e Ali (I522)

Hunting lodge-palace in Khoy

Shah Tahmasb (I 524-1 576)

Additions to Ardabil Shrine I 534-I 54Os; courtyard façade of the Dar al-Huffaz and the tomb chambers, the Jannat Sara (c. I 540), Dar al-Hadith (?)

Beginning construction at Qazvin, I 544/5

\section{QAZVIN (I555/6-I598)}

Shah Tahmasb (I 524-I 576)

Refurbishment of the Maydan-e Asb (hippodrome)

Addition of Ali Qapu Gateway between the Maydan and the royal precinct

Sa'adatabad palace precinct (Daulatkhane) with gardens and pavilions

The Chehel Sotun Palace, completed c. I 55 5/6 


\section{ISFAHAN ( $1598-1722)$}

\section{Shah Abbas I ( $1587-1629)$}

I 590/I, commencement of construction in Isfahan, Maydan-e Naqsh-e Jahan, the Qaysariyye, the Ali Qapu as a two-story gateway into the royal gardens

c. I 596, beginning of construction of the Chahar Bagh Promenade and the Hezar Jarib royal pleasance

I 598, official transfer of the capital to Isfahan

c. I 598, Ganj Ali Khan complex for governor of Kerman

c. I602, modification of the Maydan periphery

I602/3-I6I8/I9, Shaykh Lotf-Allah Chapel-Mosque

I602/3-I6I5, Ali Qapu raised to five-story tower as a Palace-Gateway

I602-I607, Allah Verdi Khan Bridge

I6I I/I 2-I638, Masjed-e Jadid-e Abbasi (Royal Mosque)

I6II, founding of cities of Farahabad and Ashraf (Cheshme Emarat, Abbasabad) in Mazandaran

Shah Safi I (1629-I642)

I630s, Talar-e Tavile and Ayenekhane Palaces

Shah Abbas II (I642-I666)

I644, talar addition to the Ali Qapu Palace-Gateway

I647-50s, the Chehel Sotun Palace

I 65 I/2, Khwaju (Hasanabad) Bridge

I650s, $\mathrm{Sa}^{\mathrm{c}}$ adatabad royal pleasance on the banks of Zayande River

I 657/8, Ju’i (Rivulet) Bridge

I659/60, Chahar Bagh-e Khwaju

Shah Solayman (I666-I694)

I669, Hasht Behesht Palace

Soltan Hossayn (I694-I722)

I 7 Io/I I, Soltani (Chahar Bagh or Madar-e Shah) Madrasa

I 7 I I, commencement of the Farahabad royal pleasance 
Neither is there aught which does not celebrate His praise.

Qur'an 17: 44 